\title{
Sustainable development and water use in New Zealand: water priority and allocation under section 5 of the Resource Management Act 1991 and the National Policy Statement on Freshwater Management 2011
}

\author{
G. Charlton \& B. Brunette \\ Faculty of Business and Law, AUT University, Auckland, New Zealand
}

\begin{abstract}
Since the enactment of the Resource Management Act 1991 (RMA) New Zealand's fresh water resources have been subject to increasing demand, challenging the ability of water resources to be redirected for new uses and threatening the ecological integrity of areas dependent upon minimum availability of water. Under the RMA, use and allocation of fresh water is determined through regional plans and the first-come first-served principle as articulated by the New Zealand High Court in Aoraki Water Trust v. Meridian Energy [2005] 2 NZLR 268. This paper explores the decision-making process for regional plans and resource consents in New Zealand (which can privilege entrenched uses, specific economic concerns of a region, or interests of organized groups) in light of the sustainability objectives of the RMA. It argues the new National Policy Statement on Freshwater Management 2011 does little to enhance the sustainability objective of the RMA because it neither affects the first-in-time priority rule for re-allocation of scarce water resources nor does it replace regional and district councils as the primary regulators of water quantity issues. These allocation decisions should be guided by a national decisionmaking entity, using national rules and guidelines to supplement local decisions. These national decision-making processes would be better able to balance the interests of existing consent holders, the general public and the environment in a manner that enhances the sustainable development objectives of the RMA.

Keywords: Resource Management Act 1991, National Policy Statement 2011, water allocation, sustainability.
\end{abstract}




\section{Introduction}

Despite being rich in freshwater resources, New Zealand waters have come under increasing pressure over the past several decades. Increased demand for agriculture, particularly dairying, coupled with environmental, human consumptive and hydro-energy have in certain instances led to over-allocation of the resources and water shortages in certain areas such as the Canterbury and Hawke's Bay. At the same time, water quality and bio-diversity dependent upon clean and a sufficient volume of water is also in decline: New Zealand's only freshwater mussel, freshwater crayfish more than $50 \%$ of its 50 native freshwater fish species and all its native frog and aquatic plants are listed as threatened (New Zealand Ministry of the Environment [1]).

These declining water quality and over-allocation quantity issues suggest that the objective of "sustainable management" envisioned under the Resource Management Act 1991 (RMA) is not being achieved in a meaningful way. On one hand, the difficulty involves the ambiguity and imprecision of the term "sustainable management" as defined in section 5 of the RMA and the reliance on policy guidelines rather than actual rules or hard standards makes the objective difficult to realize on the ground. In part this imprecision is due to the notion that sustainable management as dynamic and context dependent concept which necessarily eschews general rules. While the courts have clarified some of this ambiguity it remains problematic in practice. On the other hand, the RMA's subsidiary principle, which seeks to devolve decisional authority to where the effects and benefits of a particular policy are most apparent, gives regional councils primary regulatory authority (Memon and Skelton [2]). Unfortunately, the councils have generally had inadequate resourcing and have been susceptible to vested and economically important interest groups. The water quality and allocation decisions have tended to be cautious and generally supportive of most applications without consideration for changing future demands (Memon and Skelton [3]).

These environmental and institutional problems form a backdrop to the new National Policy Statement on Freshwater Management 2011 issued by the New Zealand Government in May 2011. A product of an extensive consultative process, the Policy Statement seeks to set out "objectives and policies that direct local government to manage water in an integrated and sustainable way, while providing for economic growth with set water quantity and quality limits" (New Zealand Government [4]). Under section 55 the RMA the National Policy Statement must be taken into consideration when making regional policy statements or plans concerning water quality and quantity. In section $\mathrm{B}$, the Policy Statement addresses the issues of water quantity and over-allocation by requiring that regional councils amend their plans to ensure that water is not "allocated to users beyond a limit' or "used to a point where freshwater objective" set forth in the Policy Statement is not met" (New Zealand Government [5]).

This paper argues that the National Policy Statement on Freshwater Management 2011 does not address the underlying institutional and legal 
problems concerning water quantity and allocation, thus making it more difficult to achieve the "sustainable management" objective set forth in the RMA. It suggests that a national decision-making authority and national environmental standards or rules rather than the national policy statements, coupled with an allocation approach which allows for permit transfers and new uses while maintaining a minimum flow which prioritises what will better be able to achieve the sustainability objectives.

\section{The Resource Management Act 1991 and water allocation in New Zealand}

While freshwater resources in New Zealand continue to be in relatively good condition when compared to other counties, there are significant water quality, allocation and use problems in some areas. Demand for water is growing. The national weekly water allocation for uses such as irrigation, domestic use and manufacturing nearly doubled between 1999 and 2010. In 2007 New Zealand had the second highest per-capita water abstraction out of 26 OECD countries (New Zealand Ministry of Environment [6]). There are quality and availability problems associated with increased intensity of land use, population growth, economic development as well as natural geographical and seasonal variability. In particular, the growing water demands for irrigation and dairying have been identified as a problem in Canterbury, Otago and Hawke's Bay. Allocation problems are also evident in the decline of indigenous aquatic species, water quality and controversies related to water flow, as these in-stream values (i.e. decisions regarding the amount of water allowed remaining in a stream for ecological and other values) are integrally related to water quantity (NIWA Taihoro Nurangi [7]). These problems pose a significant threat to major industries such as agriculture and tourism while fundamentally challenging New Zealand's "clean green" image which has been an important element of its selfidentity and has been an important element in international trade and tourism promotion.

As of 2010, New Zealand authorities had issued approximately 20,500 consents to withdraw freshwater from surface and groundwater sources. Two hundred of these consents were for non-consumptive allocations (i.e. the source water is returned and is available for other uses) such as hydro power, $68 \%$ involve the withdrawal of ground water, $29 \%$ for surface water and $3 \%$ for storage. The highest use category is for irrigation (75\%) followed by drinking water and industrial uses (9\% each). Agricultural stock accounts for $6 \%$ of all consents but a majority of such stock usages are non-consented because they fall within the reasonable use or permitted activity criteria under the RMA (New Zealand Ministry for the Environment [8]). The allocation for consumptive uses totals nearly 27 billion cubic meters per year $\left(\mathrm{Bm}^{3} /\right.$ year $)$, a volume roughly equivalent to about $46 \%$ of Lake Taupo. Excluding hydro generation, the annual allocations for Canterbury and Otago, regions which have most problems with water shortages and seasonal variations, equate to $46 \%$ and $23 \%$, respectively, of total national consumptive allocation (New Zealand Ministry for the 
Environment [9]). Approximately $65 \%$ of the maximum consented volume is actually abstracted from surface and groundwater, and most regions use less than $50 \%$ of the maximum consented volume (New Zealand Ministry for the Environment [10]). Nevertheless, there is insufficient research in many regions regarding the total quantity of water, including minimum river flows, that is actually available for consumptive uses and resource consents (NIWA Taihoro Nurangi [11]).

While over-all levels of water use suggests that there is generally sufficient water supplies in many regions, the Report of the Land and Water Forum noted "many catchments are over-allocated or approaching full allocation" and water shortages are "an increasing problem in some areas" (Land and Water Forum [12]). This echoes and earlier 2005 report by the Parliamentary Commissioner for the Environment who observed that the rapid expansion of irrigation in Canterbury, and the subsequently abandoned Aqua Project on the Waitaki River, put "the spotlight on the weaknesses in our [water] allocation mechanisms" (Williams [13]). For example, in Canterbury Region, which has consented over 600,000 hectares for irrigation, water demand from all users has contributed to 28 of its lowland streams being subject to full or partial water withdrawal restrictions, 10 "red-zones" where water is considered to be fully or overallocated and 4 "yellow zones" where water is considered to be $80 \%$ allocated (Canterbury Mayoral Forum [14]). Also in Canterbury, the central Government intervened to establish the Waitaki Water Allocation Board to manage the allocation of water rights in the Waitaki Catchment following unresolved competing claims to water from rural interests and electricity generators; and in 2010 controversially replaced the elected councilors of Environment Canterbury with government appointees. Auckland and Northland regions also faced significant shortages in summer 2010 due to drought conditions while pressure on urban water supplies, such as the Kapiti Coast have led to water conservation policies. These problems may be exacerbated by the central government's recent proposals to spend \$35 million over the next five years under an Irrigation Acceleration Fund "to support the development of irrigation infrastructure proposals to the investment-ready prospectus stage" as well as a willingness invest up to $\$ 400$ million as a minority partner in public-private partnerships to build new irrigation infrastructure. The projected funding, according to Agriculture Minister David Carter, could irrigate an additional 340,000 hectares of agricultural land (Smellie [15]).

The RMA establishes the regulatory environment for freshwater. Among other things, the RMA requires that the plans do not result in a reduction of water quantity and quality in any water bodies unless it is consistent with the purpose of the RMA. It regulates the allocation and abstraction of water and controls the discharge of contaminants into waters such that no adverse affects will occur rendering the freshwater unsuitable for consumption or resulting in adverse affects on aquatic life (Resource Management Act 1991 [16]). The primary regulators of freshwater quality and quantity under the RMA are regional and district councils. Under section 30 regional councils are responsible for the management of air, water, coastal marine areas and soil, while under 
section 31 district councils are responsible for the management of lands uses and subdivisions. Both councils have overlapping regulatory authority affecting the management of water resources (Canterbury Regional Council [17]). Regional Councils are required to prepare and implement Regional Policy Statements (RPS) which provide an overview of resource management issues and include policies and guidelines which would allow for the integrated management of all natural and physical resources in the region (s. 59). The Regional Council may also prepare a regional plan which can include standards or rules to facilitate the implementation of the RPS. Regional and District plans must incorporate the policies and guidelines set for in the RPS [s. 67(3) and s. 75(3)] (Land and Water Forum [18]). Resource consents are required for any activity which will have any actual or potential adverse affect of water quality or quantity (s. 104 and s. 105).

All regional plans address issues of water quantity but differ in the degree of specificity to particular water bodies, the relative values accorded various uses of water and allocations, the kind of limits used as a baseline to assess the effect of a proposed abstraction (e.g. maximum flow, minimum flow) and the regulatory mechanism used to implement the required limits (Land and Water Forum [19]). Thirteen of the 17 councils have set allocation limits to water abstraction. Three of these councils (Canterbury, Otago and Taranaki) have established a system which provides for priority orders based on a tiered allocation system. Under this system, water allocated to the lowest tier is only available at higher flows and will be reduced first if stream flows/volumes decrease below a lower limit. Eight regional plans include methods to address over-allocation but do not identify over-allocated catchments to which these methods would apply. The councils often use non-regulatory approaches such as voluntary reductions and water storage during period of shortages, but they also have used the resource consent renewal process and consent lapsing to address over-allocation issues (Papakaio Water Users Group [20]).

The RMA has been hailed as one of the first environmental statutes to embrace "sustainability" as a core concept in natural resource management. Part 2 , section 5 sets forth the environmental objective and defines the concept of "sustainable management" as it is intended to be realized through council and district plans and policy statements (Resource Management Act 1991 [21]). Section 5 (along with sections 6, 7 and 8) has been understood by the Courts as the "engine room" of the RMA, which is "intended to infuse the approach to its interpretation and implementation throughout" unless it is specifically excluded or limited by another provision (John Woolly Trust [22]). Nevertheless Part 2 of the RMA, and in particular section 5, has engendered considerable commentary and judicial decision-making as authorities have attempted to implement its mandate in actual policy guidelines or rules (Nolan [23]). In part this difficulty is due to the judicial determination that section 5 is to be given a broad reading by the regulatory bodies and the implementation of "sustainable management" is realized in specific contexts under the regional and district plans overseen by the local authorities and specialised regulatory bodies. As noted by Justice Grieg in New Zealand Railroad Ltd v. Marlborough District Council: 
This Part of the Act expresses in ordinary words of wide meaning the overall purpose and principles of the Act. It is not, I think, a part of the Act which should be subjected to strict rules and principles of statutory construction which aim to extract a precise and unique meaning from the words used. There is a deliberate openness about the language, its meanings and its connotations which I think is intended to allow the application of policy in a general and broad way. Indeed, it is for that purpose that the Planning Tribunal, with special expertise and skills, is established and appointed to oversee and to promote the objectives and the policies and the principles under the Act (New Zealand Railroad Ltd [24]).

This contextual holistic interpretative approach seeks to incorporate "social, economic and cultural concerns (including issues of equity)" within the policies, guidelines and rules which seem to operationalise section 5 (New Zealand Railroad Ltd [25]) - and necessarily involves linking and balancing the competing stakeholders with the social, economic, aesthetic conditions as they are nested within the broader natural and physical "environment" (Resource Management Act 1991 [26]). The Courts and the appropriate regulatory authorities must "weigh all the relevant competing considerations and ultimately make a value judgment on behalf of the community as a whole" when implementing the RMA (Tainui Hapu [27]). This view was articulated in Mangakahia Maori Komiti v. Northland Regional Council where Judge Bollard in determining a dispute over irrigation rights observed:

Paragraphs (a), (b) and (c) of s 5(2) are sometimes spoken of as "bottom line" requirements. Yet, one's immediate inclination is not to place too much reliance upon such a catch phrase. It seems preferable to approach the three paragraphs on the footing that each is to be afforded full significance and applied accordingly in the circumstances of the particular case, so that promotion of the Act's purpose is effectively achieved (Mangakahia Maori Komiti [28]).

However, such a broad gloss conflicts with the approach to section 5 which understands sustainable management "as primarily (and perhaps exclusively) concerned with balancing or controlling the effects of economic) activities on the bio-physical environment" (Grundy [29]). From this perspective, "sustainable management" while remaining wedded to a precautionary approach deemphasizes socio-economic and cultural concerns to focus instead on the application of section 5(2)(c), which enables the decision-maker to choose between "avoiding, remedying, or mitigating any adverse effects" that a particular activity might cause. This approach is evident in the pre-RMA decision Keam v. Minister of Works and Development where the Court of Appeal considered water consents under the Water and Soil Conservation Act 1967.

... any proposed use of natural water should be a beneficial use, and that the loss which might follow from the taking of the water should be weighed against the benefit which will result from its use ...where some 
adverse effect may follow ... the kind of balancing envisaged ....appears to be only a matter of common sense and thoroughly in accord with the purposes of the Act ...there may be cases where the ... broad test will be inappropriate .... For example there might be an application to abstract some water for a limited term from a source of supply so abundant.... In that kind of case it would be wrong ... to apply the benefit test in any exacting way. ..a weighing of advantages and disadvantages is not required if there are no significant disadvantages (Keam [30]).

The differing views applying the principles of section 5 to how water resources should be allocated and managed under the RMA is complicated by the general policy adhesion to first-in-time priority on allocations by regional and district councils and the determination by the High Court that water use consents are type of a quasi-property interest in Aoraki Water Trust v. Meridian Energy [31]. The dispute in Aoraki Water Trust arose when the Mackenzie and Timaru District Councils granted the Aoraki Trust consent to take water for irrigation from Lake Tekapo. At the time of the consent to Aoraki Trust, Meridian Energy had been using water to generate electricity at power stations in the South Canterbury. Meridian and its predecessors had dammed, diverted and used water under a series of consents since 1929 and 1968 and the Canterbury Regional Council had issued the additional 25 year consents in 1991. Meridian argued that due to the consents already issued the water resource was fully allocated and there was no surplus available for use by the Aoraki Trust. In response the Aoraki Trust argued that previously issued water permits do not limit a council's discretion to grant additional permits "to any other person to take, divert and/or use the waters...notwithstanding that the grant of such consents reduces the amount of water available to [Meridian] to store in the lake and use at its generation stations" (Aoraki Water Trust [32]).

In effect, Aoraki Trust argued that a water permit is a bare license and does not pass an interest or transfer property in anything. Rather, it only authorizes the holder to act in a way that would otherwise be unlawful by allowing the holder of the permit to take, use or divert water under section 14 of the RMA [33]. As such, an existing consent does not prevent an issuing authority from considering and accounting for the reasonable needs of competing users of the resource by issuing additional consents (Aoraki Water Trust [34]). In support of this proposition, Aoraki Trust relied upon the case Stanley v. South Canterbury Board where the court held that a permit holder "has no guarantee of or priority for the quantity of water specified in the permit...[and]...must accept the possibility that the source of water...may be diminished...by the demands of others lawfully entitled to use the water" (Stanley [35]).

Ironically, the High Court distinguished Stanley by observing it had been decided under the Water Conservation Act 1967. The Court noted that Stanley did not address the threshold question of "whether a consent authority under the Resource Management Act [can] grant a permit to use a resource which is already fully allocated by an existing grant" (Aoraki Water Trust [36]). Instead relying on Fleetwing Farms Limited v. Marlborough District Council, where the Court of Appeal adopted a "priority in time" standard for determining priorities 
on resources, the Aoraki Court concluded "on a plain reading [of the statute it] does not empower the consent authority to grant a consent to Aoraki in circumstances where the resource is already fully allocated to an existing holder" (Aoraki Water Trust [37]). This is because the resource consent creates an expectation of continued use or possession of the use within the outlined parameters of the consent in a manner analogous to property interest.

Part 6 of the Resource Management Act codifies the constituent elements of a resource consent, covering its nature, duration, expiry, review and transfer. A number of specific provisions ....elevate the status of water permits from something of the nature of a bare licence to a licence plus a right to use the subject resource. In that sense it has similarities with a profit à prendre.... (Aoraki Water Trust [38]).

Due to the legitimate expectation to be secure in, and to use property absent a statutory defeasement, the Court held that an authority may not issue additional consents to fully allocated water resources such as Lake Takepo since "the principle of non-derogation from a grant is applicable in all legal relationships which confer a right in property Aoraki Water Trust [39]. "In our judgment," wrote the Court:

granting a water permit for a particular volume of water over a specified period of time commits the consent authority to that grant in the sense that it is not entitled to deliberately erode the grant unless it is acting pursuant to specific statutory powers (Aoraki Water Trust [40]).

\section{The National Policy Statement for Freshwater Management 2011: are objectives and general policies enough?}

The political and environmental problems associated with over-allocation of waters, changing water demands due to the shifting population, industrial, hydroelectric and agricultural patterns, climate change, declining water quality and the concomitant increase in threatened aquatic species as problems that are not easily resolved. Nevertheless several legal, institutional and policy issues concerning water quantity and allocation remain particularly problematic and have not been addressed by the recent National Policy Statement on Freshwater Management 2011 (NPS).

In May 2011 the central government released the NPS (only the $5^{\text {th }}$ published under the RMA) in an effort to set out a policy framework for quality and quantity standards in regional and district councils. Under the RMA, regional councils will need to take the NPS objectives and policies into consideration when making regional policy statements or plans. The NPS was initially proposed prior to the 2008 election, when the Labour-led Government released a proposed National Policy Statement on Freshwater Management and appointed a board of inquiry to hear and consider submissions on the proposed policy. The Board of Inquiry submitted its report, recommendations and draft policy in January 2010. The National-led Government subsequently asked the Land and 
Water Forum how it should proceed. The Forum recommended that the Board of Inquiry's draft NPS Statement be adopted with some changes (Land and Water Forum [41]). The Government made some additional changes to the draft NPS and issued it in May 2011. The new NPS sets forth objectives and policies relating to water quality and water quantity, integrated water management and Tangata whenua roles and interests. It seeks to protect the ecological capacity and processes for water and seeks to maintain or improve the "overall quality of fresh water with a region...." (Government of New Zealand [42]). Under the NPS, regional councils will be required to establish environmental flows and the aggregate capacity of freshwater resources in order to "to safeguard the lifesupporting capacity, eco-system process and indigenous species...in sustainably managing the taking, using, damming, or diverting of fresh water" (Government of New Zealand [43]). These baseline standards would enable councils to better assess the conflicting objectives of the RMA consent process, avoid overallocations and in the case of present over-allocation, provide the basis to lower permitted abstractions. The councils are also to implement policies providing for the efficient allocation and use of water by specifically including within their plans the "criteria by which applications for approval of transfer of water take permits are to be decided", and identifying methods "to encourage the efficient use of water" (Government of New Zealand [44]). Where water bodies do not meet the NPS objectives, councils are directed to specify targets and methods to achieve those targets within a specified time frame. Regional councils are obligated to "implement the policy as promptly as is reasonable in the circumstances" and it must be "fully implemented by 31 December 1930" (Government of New Zealand [45]).

The central government has suggested the NPS will have a positive effect on water quality and quantity in the coming decades. However it is unlikely that the NPS will have more than a marginal impact on water allocation issues. First, the first-come-first-served allocation principle as understood in Aoraki Water Trust must be modified by legislation to allow councils to redirect water toward new beneficial uses, or re-allocate water for off-stream purposes involving agriculture, household, industry and fish and wildlife habitats. Under the current version of the RMA, councils do have the right to review existing water abstraction consents or re-direct water to new uses where the resource is overallocated. Sections 30 and 68(7) of the RMA enable a council to control the quantity, level and flow of any water body. Section 128 provides that the conditions of the resource consent may be reviewed where there are adverse affects on the environment which arise because of a authorized use or where a regional plan "has been made operative which sets rules relating to maximum and minimum flows" (Resource Management Act 1991 [46]). However, the current process is lengthy and can be subject to many appeals and reviews. The Aoraki Water Trust decision impacts this regulatory framework because it equates granted resource consents is analogous to "property" and as such raises the burden of proof on regional councils in determining adverse affects. One result of this "quasi-property" notion of a permitted abstraction is that "[w]here a resource is fully allocated in a physical sense ... the consent authority cannot 
lawfully grant another party a permit to use the same resource unless specifically empowered ...." (Aoraki Water Trust [47]). Thus where a catchment is overallocated, it is ultra vires for the council to lower the permitted volumes to current resource consent holders in favour of new uses. Another result is that after Aoraki Water Trust, a council must prove that the reviewed consent has had the claimed adverse effect to revise the consented volume downward. A legitimate expectation which arises from possession of a property interests, plus the concomitant right to exclude others from the use of such property would be meaningless without such judicial protection. Where the resource is fully allocated, and there are no adverse effects for the current consented uses, the legitimate expectation of the consent holder to have use of a minimum guaranteed flow precludes new uses which may be more efficient. It also precludes the implementation of a policy aimed at maintaining the overall water quality (dependent as it is on water quantity available to in-stream values) in the region. The legal and technical imprecision that can accompany the determination of total volumes and the impact various smaller abstractions may have on in-stream values coupled with the high-stakes nature of water allocation disputes will be an obstacle to changing the status quo despite an over-allocation (Peart [48]).

This equation of water consents with a usufructuary right for the term of the consent period is not in itself problematic, but must be modified by legislation to eliminate the accoutrements that accompany a "property" interest in a particular volume of water. As noted by David Grinlinton:

Use of mechanisms such as easements, restrictive covenants, leases and licences can assist in protection of environmental values without interfering with property ownership. Tradeable permits for water and emissions "budgets" with tradable permits to control atmospheric pollution provide further examples of "free market environmentalism" (Grinlinton [49]).

The NPS does address this issue by requiring clear criteria for the transfer of water permits, but is does not address the legitimate expectations given consent holders under Aoraki, nor does it outline any potential mechanisms (though it is clear that a market for water permit transfers is desirable) or criteria by which an "efficient allocation" may be achieved (Government of New Zealand [50]). One useful approach that could diminish the impact of Aoraki would be to convert a permit which entitles the holder to a certain volume of water to a percentage share of the water resource similar to the approach taken in fisheries quotas in New Zealand. Under this scenario, the permitted percentage share would not exceed the amount of water necessary to protect in-stream values as well as potential new uses should the council seek to allocation water to that use. If the council chooses not to allocate water to new uses, existing consent holder may use the water in an ordinary manner but have no expectation that such use will continue. Alternatively, an approach similar to the American doctrine of "equitable apportionment" which allows for re-allocations based on a variety of factors such as existing uses, changing physical and climatic conditions, the practical effect of wasteful uses on 
downstream areas, storage availability and economic efficiency could be used to enable councils to re-direct water allocations (South Carolina v. North Carolina [51]). Additional principles related to anti-monopolistic regulatory regimes which prevent crowding out of small users and new uses by existing industries or users could also be investigated with a lower burden of proof upon the councils to justify their allocation change decisions.

Second, the primary regulatory bodies under the RMA must be moved to the national level. While the RMA generally provides councils with a range of policy instruments to address quantity and allocation issues the regulatory reliance on regional and district councils and the use of policy guidelines rather than regulatory, rules has been less than successful (Simpson Grierson [52]). As noted by the Land and Water Forum:

Few regional councils have had the consistent and coherent policy and planning frameworks to put the necessary management regimes in place. In the nature of things it is difficult to get agreements about what limits should be, how quickly they should be achieved and who should bear the cost - but stakeholders and iwi [Maori tribes] have not always been fruitfully engaged, either at the national or the regional levels. Monitoring and enforcement of rules, consents and their conditions is also variable (Land and Water Forum [53]).

Regional and district councils are generally underfunded and are short on the types of legal and scientific expertise necessary to draft and enforce plans which preserve and allocate water resources or reverse the adverse affects of current activities on water. The appeals process built into the RMA exacerbates these problems and councils have generally only been able to complete and implement plan changes with a large amount of financial assistance from the central government. As such, the two most difficult policy problems over which regional councils have jurisdiction under the RMA: how do you allocate water in order to preserve and allow for increases in existing uses while allowing for new uses and users, and how does one preserve the innate cultural and ecological values in the face of increased demands have generally not been addressed by the regions (Miller [54]). Regional councils have had difficulty dealing with the highly complex nature of water issues that come before them. It is difficult to achieve the appropriate balance among the economic, social, cultural and environmental factors that must be taken into account under the RMA. Allocation issues (and to a lesser extent water quality issues) have a certain "zero-sum" logic to them where a desired policy outcome for an interested party, is or is perceived to be, completely antithetical to the another interested party's preferred outcome creates a highly charged political atmosphere. Stakeholders and interested parties are politically energized and find it difficult to empathize or compromise in the generally adversarial structure embedded with the consent process. This difficulty is compounded by the perception that some regional process and regulatory bodies are "biased" or more amenable to certain ideological, political and economic arguments. In Canterbury, the evident mistrust of stakeholders and interested parties in the fairness of the regional regulatory processes and 
decision-making has undermined the RMA process and required intervention by the central government (Government of New Zealand [55]). The result has been that councils have generally been conservative in the application of the RMA, have tended to have a "built-in" ambiguity in their policies and standards, or have been slow to enact standards or determine the requisite required in-flow values or total amounts of water available for allocation, and often rely on nonregulatory collaborative approaches to water issues. These non-regulatory approaches have historically been ineffectual, if one considers the general deterioration of water quality across the country and increased allocation problems (Environment Waikato [56]). While such decisional "space", discretion and room for stakeholder consultation regarding policy instruments is generally desirable under the RMA - after all "sustainable management" seeks to realize sustainable outcomes within particular contexts - the results have tended to favor the prevailing environmental, social, economic and cultural status quo (Miller [57]). At the same time, the democratic de-centralized ethos which was envisioned within the RMA has paradoxically had the effect of "obscuring political accountability". The very process obfuscates continued inaction or failure to materially achieve sustainable management policies (McLean [58]). Moreover, the lack of confidence in, or inability of some regional regulators to meet either the needs of various stakeholders will increase the likelihood of further central government interventions as unresolved allocation impact water availability.

In these circumstances, a national agency would be better able to deliver on the RMA's objective of sustainable management. The agency would be able to amass the requisite expertise and funding, something which the Land and Water Forum noted was lacking in New Zealand, while insulating itself from the more desultory political and economic pressures that can affect regional decisionmaking. As required by prudent integrated water management practices, the national agency would continue to establish quality and quantity limits on a catchment and regional basis with regional assistance but decisional authority along with political and technical accountability would be centralized and clarified. The process would develop an even environmental response across the country and also free up the resources of regional councils to address issues that are unique to the regions (Miller [59]). This would lessen the perceived unfairness that has arisen at the regional level when applications with greater community benefit are not given priority. The groundwork for such an agency has already been laid, as the Resource Management (Simplifying and Streamlining) Amendment Act 2009 established a national environmental protection authority to process consent applications which concern on projects of "national significance" as well as establish national environmental standards.

Third, the national agency must promulgate and enforce specific national quality, quantity and allocation standards or rules rather than objectives, guidelines, policies or assessment criteria used in the NPS or in many regional plans. Only specific rules in relation to environmental flows, water levels, and water pressures are specifically enforceable under the RMA. As such, Water allocations and takes, diversions and discharges can be controlled by reference to 
rules which could regulate the location, timing, volume and rate of diversion or abstraction, end use etc. Perhaps the most desirable aspect of using rules or standards is the clarity and certainty they provide concerning the type and conditions of a permitted activity, thus aiding enforcement as well as their ability to limit the discretion of the consent authority (Merz [60]). These national standards would be desirable even if regional authorities were primary regulators because the devolution of management and decision-authority obtain the best results when there are clear and well-designed standards. Regions could be allowed to establish and enforce higher standards than the national standard, similar to the Clean Water Act in the United States, but there would be a national minimum below which regions could not venture. Standards and rules would allow for more clarity in consent processes with clearly defined and preconditions for obtaining a permit.

Moreover, the national standards should not be premised on the more holistic concept of "sustainable management" as outlined in the RMA. Rather, they should be based on an allocation and quality limits to protect in-stream values, thresholds for each catchment area and an integrated "Ecological or environmental flow standard" (what the New Zealand Ministry of Environment refers to as "Ecological flows", i.e. standards which relate only to protecting specific ecological components and/or ecosystem health and/or functioning/ processes in water short areas). This would allocate water to the eco-system first prior to other interests outlined in Part 2 or elsewhere in the Act. The logic of "sustainable management" with its more anthropocentric vision of in-stream values and water use should overlay this ecological baseline. In some instances, an ecological flow approach to water management would be congruent with spiritual or cultural interest of Tangata whenua. The approach is consistent with the 2010 Board of Inquiry's recommendation that the NPS give precedence to bio-physical, intrinsic and other in-stream values over other uses. It is also part of British Columbia's proposals to modernize its Water Act and has been suggested in the 2008 interim rules put forth by the New Zealand Ministry of the Environment. Ironically, the adoption of such an approach would provide a more identifiable ground against which to measure the "sustainable management" objectives of the RMA which will need to be amended to emphasize the priority of ecological systems and processes in areas of water shortages.

\section{Conclusion}

It is ironic that despite the passage of the RMA, New Zealand's water resources have generally deteriorated. Progress has been made on point-source pollution but the country's regulatory apparatus is in need of some substantial changes if the environmental, social and economic challenges of the future are to be met. While New Zealand has commendably pushed natural resource decision-making downward under the RMA in an effort to consider all the interests affected by the natural resource use, it is essential that the central government become more involved in water allocation issues. The policy guidance set forth in the National Policy Statement on Freshwater Management 2011 does not address the 
underlying institutional and legal problems in the area. Regional councils remain the primary regulators of water and they have not been particularly effective under the RMA regulatory process. They are short of the resources necessary to implement Part 2 of the RMA. As the NPS allows councils until 2030 to implement rules pursuant to the announced objectives and policies, the New Zealand public will face an increasing number of allocation problems. Some of these changes discussed above, such as establishing national environmental agency to promulgate national standards and rules, as well as oversee the water allocation process through the centralisation and scientific and regulatory expertise, can be made without changing the RMA. Reversing the Aoraki Water Trust decision, promulgating minimum flow and allocation rules which give precedence to bio-physical, intrinsic and other in-stream values or clarifying the definition of "sustainable management" would require legislative changes. In any event, the necessary changes to reverse the decline in New Zealand water recourses will involve the application of political will and experimentation for which the New Zealand polity is well known.

\section{References}

[1] Environment New Zealand 2007; New Zealand Ministry of the Environment, p. 367; Joy, Mike., "The Dying Myth of a Clean, Green Aotearoa," New Zealand Herald April 25, 2011.

[2] Memon, A. \& Skelton, P., Institutional Arrangements and Planning Practices to Allocate Freshwater Resources in New Zealand: A Way Forward.11 New Zealand Journal of Environmental Law, 11, p. 251, 2007.

[3] Ibid., pp. $254-5$.

[4] National Policy Statement for Freshwater Management, 2011; New Zealand, Online. http://www.mfe.govt.nz/publications/rma/nps-freshwatermanagement-2011/docs/nps-freshwater-mgnt-2011.pdf. p. 3.

[5] Ibid. at 5.

[6] Freshwater Availability and Use. New Zealand Ministry of Environment, Online. http://www.mfe.govt.nz/issues/water/freshwater/index.html

[7] See Analysis of national river water quality data for the period 1998-2007 (updated 2010), CHC2010-038. NIWA Taihoro Nurangi, Online. http://www.mfe.govt.nz/publications/water/analysis-of-national-riverwater-quality-data-1998-2007/analysis-of-river-water-quality-final.pdf.

[8] Freshwater Allocation National Environmental Indicator (2010). New Zealand Ministry for the Environment, 2010, Online. http://www.mfe.govt.nz/publications/ser/enz07-dec07/html/chapter10freshwater/page2.html, p. 13.(check)

[9] Ibid., p. 3. The overall allocations of water (including the non-consumptive uses such as hydro-generation) account for $193 \mathrm{Bm}^{3} /$ year.

[10] The actual water use as a percentage of consented volumes is highest in Gisborne followed by Southland and Auckland regions. Ibid., p.5, 33 .

[11] In 2008 the Ministry for the Environment proposed a National Ecological Standard for environmental flows and water levels. The Standard proposed 
'interim limits' for water allocation, based on hydrological rules of thumb that are applied nationally. Currently, NIWA Taihoro Nurangi is updating the system to make it more sensitive to local variations of flow. NIWA Taihoro Nurangi, Online. http://www.niwa.co.nz/our-science/ freshwater/publications/all/wru/freshwater-update-45\%2C-may-2011/ research-update---defining-acceptable-river-flow-regimes.

[12] Land and Water Forum, 2010. Report of the Land and Water Forum: A Fresh Start for Freshwater, p. ix.

[13] Williams, J. M., New Zealand House of Representatives. Report of the Parliamentary Commissioner for the Environment for the year ended 30 June 2005. Online. http://www.pce.parliament.nz/assets/Uploads/ Reports/pdf/annual_report_05.pdfat.,

[14] Canterbury Mayoral Forum. (2010). Canterbury Water Management Strategy, pp. 12, 22-25. Online. http://www.canterburywater.org.nz/ downloads/cwms-strategic-framework.pdf . The Forum noted that in 2006 there were full or partial withdrawal restrictions on 28 of 57 lowlands streams, partial restrictions on 13 of 36 foothill rivers and partial restrictions on 2 of 7 alpine rivers.

[15] Smellie, P., "Budget 2011: Govt brings irrigation schemes to market," Stuff.co.nz, 9 May 2011. Online. http:/www.scoop.co.nz/ stories/BU1 105/S00304/budget-2011-govt-brings-irrigation-schemes-tomarket.htm.

[16] Section 14 of the RMA reads in part: Restrictions relating to water - (1) No person may take, use, dam, or divert any -

(a) Water ...unless the taking, use, damming, or diversion is allowed by subsection (3).

(b) A person is not prohibited by subsection (1) from taking, using, damming, or diverting any water ... if -

(c) The taking, use, damming, or diversion is expressly allowed by a rule in a regional plan and in any relevant proposed regional plan or a resource consent ....

[17] Canterbury Regional Council v. Banks Peninsula District Council, [1995] NZRMA 452 (CA).

[18] Land and Water Forum, 2010. Report of the Land and Water Forum: A Fresh Start for Freshwater, pp.17-20.

[19] Ibid., p. 23. See also Mertz, S.K., Regional Council practice for setting and meeting RMA-based limits for freshwater flows and quality. New Zealand Ministry of Environment. 2010.

[20] Papakaio Water Users Group v. Otago Regional Council, C68-01/2001 (non-regulatory approach to ground water allocation in plan approved) ; Otago Water Resource Users Group v. Otago Regional Council, C88/2003 (Holders of water use consents must be vigilant to protect interest, no additional obligation on public authority to reserve or assure existing consent holders maintain allocation after date of consent expiration ).

[21] RMA s. 5(1) and (2) reads in part: (1) The purpose of this Act is to promote the sustainable management of natural and physical resources. 
(2) In this Act, sustainable management means managing the use, development, and protection of natural and physical resources in a way, or at a rate, which enables people and communities to provide for their social, economic, and cultural well-being and for their health and safety while -

(a) sustaining the potential of a natural and physical resources (excluding minerals ) to meet the reasonably foreseeable needs of future generations; and

(b) safeguarding the life-supporting capacity of air, water, soil and ecosystems; and

(c) avoiding, remedying, or mitigating any adverse effects of activities on the environment.(bold in original).

[22] Auckland City Council v. John Woolly Trust [2008] NZRMA 260 (HC) at para. 47 (Randerson J). "The heart of the RMA is the statement of purpose and principles in Part II. Section 5 includes the purpose of promoting the sustainable management of natural and physical resources in a way which enables people and communities to provide for their social, economic and cultural well being. Section 7 imposes on decision-makers the obligation to have particular regard to the ethic of stewardship, the efficient use and development of natural and physical resources, the maintenance and enhancement of amenity values and the enhancement of the environment ..." see also Progressive Enterprises Ltd v. North Shore City Council [2006] NZRMA 72 (HC) at para. 8.

[23] Nolan, D., Environmental and Resource Management Law, Lexis Nexis: Wellington, p. 103, 2005.

[24] New Zealand Railroad Ltd v. Marlborough District Council [1994] NZRMA 70 (HC), p. 86.

[25] Ibid., p. 71.

[26] Section 2 of the RMA defines "environment" to include:

○ (a) ecosystems and their constituent parts, including people and communities; and

○ (b) all natural and physical resources; and

- (c) amenity values; and

- (d) the social, economic, aesthetic, and cultural conditions which affect the matters stated in paragraphs (a) to (c) or which are affected by those matters

[27] Tainui Hapu v. Waikato Regional Council, ENC Auckland A063/2004, 10 May 2004, para. 181, citing Watercare Services v. Minhinnick [1998] NZRMA 113 (ENC).

[28] [1996] NZRMA 193, 210, 214.

[29] Grundy, K. Purpose and Principles: Interpreting Section 5 of the Resource Management Act. eds, P. A. Memon \& H. Perkins, Environmental Planning \& Management in New Zealand, Dunmore Printing Company Ltd: Palmerston North, NZ, pp. 64, 70, 2000.

[30] Keam v. Minister of Works and Development [1982] 1 NZLR 319 at 323 (CA). 
[31] Aoraki Water Trust v. Meridian Energy [2005] 2 NZLR 268 (HC) (Aoraki Water Trust).

[32] Aoraki Water Trust at 273.

[33] Under section 14(1) of the RMA no person may "take, use, dam, or divert any water", or heat or take energy from material surrounding geothermal water unless with a consent or within an exception provided for in the Act or in a regional plan. Section 14(3) provides that water may be taken without a consent for "an individual's reasonable domestic needs" or "the reasonable needs of an individual's animals for drinking water" provided the taking or use does not or is not likely to adversely affect the environment.

[34] Aoraki Water Trust at 276.

[35] Stanley v. South Canterbury Board, (1971) 4 NZTPA 63 at 68.

[36] Aoraki Water Trust at 276.

[37] Aoraki Water Trust at 283.

[38] Ibid. at 279.

[39] Ibid.

[40] Ibid. at 281

[41] The Land and Water Forum in part recommended: 1) the NPS refer to Tangata Whenua roles and Maori values and interests; 2) change policy C1 to include reference to "mitigate" in achieve promulgated standards, 3) clarify what contamination means in relation to objectives. Land and Water Forum, 2010. Report of the Land and Water Forum: A Fresh Start for Freshwater, p. 5.

[42] The Cabinet paper on NPS acknowledges that this objective means that some freshwater will be further degraded provide the regional council can improve it in other water bodies. "The objective also recognises that a bottom line of at least maintaining water quality everywhere is not possible. It allows for some variability in terms of water quality as long as the overall water quality is maintained in a region. Essentially, it allows for offsets with a region, including between catchments." NZ: Cabinet Paper. National Policy Statement for Freshwater Management, p.6, paragraph 33. Available at http://www.mfe.govt.nz/cabinet-papers/freshwaternps.pdf

[43] National Policy Statement for Freshwater Management, 2011; New Zealand, Online. http://www.mfe.govt.nz/publications/rma/nps-freshwatermanagement-2011/docs/nps-freshwater-mgnt-2011.pdf p. 8.

[44] Ibid.

[45] Ibid., 11.

[46] s. 128, RMA.

[47] Aoraki Water Trust at para. 46.

[48] "The granting of water licences on a 'first come first served' basis and the failure of water licence trading to be generally adopted in New Zealand have resulted in an inflexible system. This makes it difficult for the allocation of water to adapt to changing economic requirements." Peart, R., Innovative Approaches to Water Resource Management: A Comparison of 
the New Zealand and South African Approaches. New Zealand Journal of Environmental Law, 5, p. 127, 153. 2001.

[49] Grinlinton, D., Property Rights and the Environment. Australian Property Law Journal 4, p. 41, 62. 1996.

[50] The NPS defines "Efficient allocation" as including "economic, technical and dynamic efficiency."

[51] South Carolina v. North Carolina, 130 S.Ct. 854 (2010).

[52] Specific methods used under the RMA to establish water quantity limits include:

a) establishing minimum and maximum flows, levels and pressures;

b) setting a maximum allocation volume for a section of river or groundwater zone;

c) allocation caps;

d) staged flow restrictions;

e) first in first served restrictions;

f) proportional reductions in take above a minimum flow;

g) establishing priorities enabling first in, last to turn off;

h) groundwater takes limited by reference to stream flows;

i) one to one flow sharing;

j) gaps between classes of permits where no water can be taken;

k) rostering;

1) temporary transfer of spare allocation during times of shortage.

Simpson Grierson, Case Law on Limits for Freshwater Quality and Environmental Flows. New Zealand Ministry for the Environment, pp. 53-56, 2010.

[53] Land and Water Forum, 2010. Report of the Land and Water Forum: A Fresh Start for Freshwater, p. 9.

[54] Miller, C.L., Implementing Sustainability The New Zealand Experience, (Routledge: London and New York, p. 60, 2011.

[55] For example, one argument for the replacement of elected commissioners on Environment Canterbury is that proponents of increased irrigation allocation felt that Environment Canterbury was unfairly prioritizing the benefit and needs of the natural environment over the needs 's of agriculture. The Review Panel appointed by the national government for Environment Canterbury noted that when it interviewed the CEO of Environment Canterbury, the CEO stated that "our title is Environment Canterbury and this is what we stand for - protecting the environment", in spite of the fact that the RMA and the Regional Plan required a the wider function. See also criticism by the Review Panel of Rakaia-Selwyn groundwater decision by Environment Canterbury. See Investigation of the Performance of Environment Canterbury under the Resource Management Act \& Local Government Act February 2010, Ref. CR 84, Online. http://www.mfe.govt.nz/publications/rma/investigation-performanceenvironment-canterbury/page2.html\#footnote3

[56] For example, Environment Waikato implemented policies to encourage farmers to voluntarily reduce run-off into streams, rivers and lakes. Despite 
some farmer adapting their practices water quality in the Waikato continues to decline.

[57] Miller, C.L., Implementing Sustainability The New Zealand Experience, (Routledge: London and New York, pp. 60-84.

[58] McLean, J., New Zealand's Resource Management Act 1991: Process with Purpose? Otago Law Review, 7, p. 538, 539, 1992.

[59] Miller, C.L., Implementing Sustainability The New Zealand Experience, (Routledge: London and New York, pp. 28-29.

[60] See Merz, S.L. Options to Improve Water Allocation Outcomes, New Zealand Ministry of Environment, 2006. Online: http://www.mfe.govt.nz/ publications/water/options-improve-water-allocation-outcomes/optionsimprove-water-allocation-outcomes.pdf 